\title{
Effect of skim milk treated with high hydrostatic pressure on permeate flux and fouling during ultrafiltration
}

\author{
Mathilde Leu, Alice Marciniak, Julien Chamberland, Yves Pouliot, Laurent Bazinet, and Alain Doyen ${ }^{1}$ \\ Institute of Nutrition and Functional Foods (INAF), Dairy Research Centre (STELA), Department of Food Sciences, Université Laval, Québec, \\ Québec, G1V 0A6, Canada
}

\begin{abstract}
Ultrafiltration (UF) is largely used in the dairy industry to generate milk and whey protein concentrate for standardization of milk or production of dairy ingredients. Recently, it was demonstrated that high hydrostatic pressure (HHP) extended the shelf life of milk and improved rennet coagulation and cheese yield. Pressurization also modified casein micelle size distribution and promoted aggregation of whey proteins. These changes are likely to affect UF performance. Consequently, this study determined the effect of skim milk pressurization (300 and $600 \mathrm{MPa}, 5 \mathrm{~min}$ ) on UF performance in terms of permeate flux decline and fouling. The effect of HHP on milk proteins was first studied and UF was performed in total recycle mode at different transmembrane pressures to determine optimal UF operational parameters and to evaluate the effect of pressurization on critical and limiting fluxes. Ultrafiltration was also performed in concentration mode at a transmembrane pressure of $345 \mathrm{kPa}$ for 130 or $140 \mathrm{~min}$ to evaluate the decline of permeate flux and to determine fouling resistances. It was observed that average casein micelle size decreased by 32 and $38 \%$, whereas $\beta$-lactoglobulin denaturation reached 30 and $70 \%$ at 300 and $600 \mathrm{MPa}$, respectively. These results were directly related to UF performance because initial permeate fluxes in total recycle mode decreased by $25 \%$ at 300 and $600 \mathrm{MPa}$ compared with nonpressurized milk, critical flux, and limiting flux, which were lower during UF of milk treated with HHP. During UF in concentration mode, initial permeate fluxes were $30 \%$ lower at 300 and $600 \mathrm{MPa}$ compared with the control, but the total flux decline was higher for nonpressurized milk (62\%) compared with pressure-treated milk (30\%). Fouling resistances were similar, whatever the treatment, except at $600 \mathrm{MPa}$ where irreversible fouling was higher. Characterization of the fouling layer showed
\end{abstract}

Received February 21, 2017.

Accepted May 1, 2017.

${ }^{1}$ Corresponding author: alain.doyen@fsaa.ulaval.ca that caseins and $\beta$-lactoglobulin were mainly involved in membrane fouling after UF of pressure-treated milk. Our results demonstrate that HHP treatment of skim milk drastically decreased UF performance.

Key words: ultrafiltration, high hydrostatic pressure, permeate flux decline, membrane resistance, protein fouling

\section{INTRODUCTION}

In the dairy industry, UF is widely used to concentrate caseins and whey proteins to produce milk protein concentrate (Marcelo and Rizvi, 2008; Pouliot, 2008; Mohammad et al., 2012; Meyer et al., 2015). Milk protein concentrates are used in the formulation of a wide range of food products due to their nutritional value and their functional properties, such as foaming, emulsifying, solubilizing, and gelling. At this time, the main application of milk protein concentrate is to standardize milk to the desired casein to fat ratio for cheese production (Huffman and Harper, 1999; GesanGuiziou, 2012).

As largely reviewed for all pressure-driven membrane processes, the main drawback in using UF for skim milk concentration is the decline in permeate flux due to concentration polarization and membrane fouling. Concentration polarization is defined as the accumulation of particles at a membrane surface, whereas fouling results from protein adsorption and protein-protein interactions on the membrane surface (formation of a deposit layer) and in membrane pores (complete or partial pore plugging). Consequently, concentration polarization and fouling can drastically reduce permeate flux and membrane selectivity, increase energy consumption, therefore negatively affecting UF performance and efficiency (Chen et al., 1997; Bacchin et al., 2006; Shi et al., 2014).

Previous studies evaluated fouling species during milk UF as a function of the initial matrix (whole/skim milk, raw/pasteurized/reconstituted) and filtration operating parameters [hydrodynamic parameters, membrane material, molecular weight cut-off (MWCO), 
and so on]. Proteins are the major membrane foulants during UF of whole or skim milk (pasteurized or not) on polyethersulfone (5 and $10 \mathrm{kDa}$; Bégoin et al., 2006) or on ceramic membranes (zirconia material, MWCO of 10 and $150 \mathrm{kDa}$; Daufin et al., 1991). However, it is still unclear whether whey proteins, especially $\alpha$-LA or casein micelles, represent the major protein foulant of membranes during UF of milk. Indeed, Tong et al. (1988) showed that fouling of polysulfone membrane (MWCO of $10 \mathrm{kDa}$ ) was mainly composed of whey proteins, especially $\alpha$-LA. Moreover, after UF (M5 Carbosep type, $5-10 \mathrm{kDa}$ ) of UHT and reconstituted skim milk, Rabiller-Baudry et al. (2005) demonstrated that the deposit layer was mainly composed of casein micelles and its permeability was governed by electrostatic interactions. Consequently, and as a function of filtration conditions, casein and whey proteins must be characterized as fouling species after skim milk UF.

Recently, high hydrostatic pressure (HHP) was studied as an emerging technology and alternative treatment for skim milk pasteurization. Pressuretreated milk was demonstrated to be comparable to pasteurized milk $\left(72^{\circ} \mathrm{C}, 15 \mathrm{~s}\right)$ in terms of microbial quality (Trujillo et al., 2002, 2016). More specifically, isostatic pressures of $400 \mathrm{MPa}$ for $15 \mathrm{~min}$ or $600 \mathrm{MPa}$ for 3 min at $20^{\circ} \mathrm{C}$ extended the milk shelf-life for $10 \mathrm{~d}$ (Rademacher and Kessler, 1997; Chawla et al., 2011). Although it has been established that HHP treatment had little effect on flavor compounds and the integrity of vitamins and other nutrients, the technology induced drastic modifications of milk color and turbidity as well as colloidal and soluble protein fractions (Balasubramaniam et al., 2016). Indeed, and depending on HHP parameters (pressure, time, and temperature), pressure treatment can have a major effect on casein micelle size distribution. For example, a treatment at $250 \mathrm{MPa}$ for 15 min increased micelle casein size due to casein aggregation, whereas a treatment at pressures greater than $300 \mathrm{MPa}$ irreversibly reduced the micelle size to approximately $50 \%$ of its initial diameter (Huppertz et al., 2002, 2006a,b; Voigt et al., 2015). The loss of micellar integrity observed after the pressure treatment was explained by solubilization of calcium phosphate, and consequently, disruption of casein micelles (Huppertz et al., 2002, 2004; Huppertz and de Kruif, 2007). Denaturation of the whey protein, $\beta-\mathrm{LG}$ was observed from $100 \mathrm{MPa}$ and increased with pressure to reach $90 \%$ at $400 \mathrm{MPa}$. However, pressurization above $400 \mathrm{MPa}$ had only a minor effect on $\beta$-LG denaturation (Considine et al., 2007a; Balasubramaniam et al., 2016). Contrary to $\beta-\mathrm{LG}, \alpha-\mathrm{LA}$ in whey is more resistant to pressurization because $\alpha$-LA is denatured from $400 \mathrm{MPa}$ with a maximal denaturation rate of $70 \%$ after 30 min at 800
MPa (Trujillo et al., 2002; López-Fandiño, 2006; Naik et al., 2013). The higher stability of $\alpha$-LA is probably due to its higher number of intra-molecular disulfide bonds and the absence of a free sulfhydryl group in its structure (Huppertz et al., 2006a). The denaturation of whey proteins combined with disruption of casein micelles generates specific milk protein interactions under isostatic pressure. It was reported that $\beta$-LG interacted with other $\beta$-LG and $\alpha$-LA through $\mathrm{SH} / \mathrm{S}-\mathrm{S}$ exchange reactions, which induced the formation of whey protein aggregates. It was also observed that $\beta-\mathrm{LG}$ can also form specific complexes with $\kappa$-CN due to their free thiol groups (Kolakowski et al., 2001; Considine et al., 2007a,b).

Consequently, considering the protein structure modifications observed on pressurization, it is conceivable that HHP-treated milks will exhibit different UF performance in terms of permeate flux decline and fouling mechanisms. The study of HPP-treated milks provides an unprecedented opportunity to better understand the contribution of casein micelles and whey proteins to membrane fouling. Thus, the aim of this study was (1) to evaluate the effect of HHP on casein micelle size distribution and whey protein aggregation in skim milk; (2) to study the effect of pressure-treated skim milk (300 and $600 \mathrm{MPa}$ for $5 \mathrm{~min}$ ) on permeate flux decline during UF in total-recirculation and concentration modes; and (3) to compare the composition of the membrane fouling layer after pressure-treated and control skim milk concentration by UF.

\section{MATERIALS AND METHODS}

\section{Milk Supply}

Pasteurized (HTST, $72^{\circ} \mathrm{C}$ for $16 \mathrm{~s}$ ) skim milk was obtained from a local distributor (Québon, Agropur Natrel Division, Longueuil, QC, Canada) and was stored at $4^{\circ} \mathrm{C}$ until used in pressurization experiments.

\section{High Hydrostatic Pressure Treatment}

High hydrostatic pressure treatments of skim milk were performed at 300 and $600 \mathrm{MPa}$ for $5 \mathrm{~min}$ at room temperature in a discontinuous hydrostatic pressurization unit Hiperbaric 135 system (Hiperbaric, Burgos, Spain) with water as the pressure transmission medium. The stainless-steel pressure vessel measured 0.30 $\mathrm{m}$ in diameter and $2.20 \mathrm{~m}$ in length with a working volume of $135 \mathrm{~L}$. A nonpressurized skim milk was used as a control. Pressurization at 300 and $600 \mathrm{MPa}$ was specifically chosen to observe the reversible and the irreversible effects of HHP on skim milk proteins. Indeed, 
although treatment at $600 \mathrm{MPa}$ induced irreversible modifications on the structure of micellar caseins and whey proteins, it was demonstrated that pressurization at $300 \mathrm{MPa}$ induced reassociation of micellar caseins through hydrophobic bonds (Chawla et al., 2011) and reversible denaturation of $\beta-\mathrm{LG}$ (Considine et al., 2007a). After pressurization, skim milk samples were stored at $4^{\circ} \mathrm{C}$ until UF experiments.

\section{Ultrafiltration System}

Ultrafiltrations of pressurized and nontreated milk samples were performed in a crossflow filtration unit (model SEPA-CF, Sterlitech, Kent, WA). The UF system included a stainless conical feed tank $(5.3 \mathrm{~L})$, diaphragm pump (M-03S Hydracell, 1.8 GPM, 230 V, 60 $\mathrm{Hz}, 3 \mathrm{PH}$ motor, Wanner Engineering Inc., Minneapolis, MN), pressure gauge located after the membrane module for transmembrane pressure (TMP) regulation, and one membrane module. The membrane module consisted of a polyvinylidene difluoride flat-sheet UF membrane (Synder Filtration Inc., Vacaville, CA) with an active filtration surface of $0.014 \mathrm{~m}^{2}$, MWCO of $10 \mathrm{kDa}$ and spacer of thickness $31 \mathrm{mil}$ on the feed side. Before each UF experiment, the pure water flux was measured in triplicate following conditioning of the UF membrane with a chlorinated alkaline solution $(\mathrm{pH}$ $10.5,50^{\circ} \mathrm{C}, 10 \mathrm{~min},<200 \mathrm{mg} / \mathrm{kg}$ ) and rinsing for $20 \mathrm{~min}$ with demineralized water. Only flat sheet membranes with a similar water flux value $( \pm 10 \%)$ were used for UF experiments.

\section{Operational Modes}

Total Recycle Mode. Total recycle experiments were carried out at different TMP to determine the optimal operational conditions for the concentration mode. Permeate and retentate streams of pressurized (300 and $600 \mathrm{MPa}$ ) and nontreated skim milk from 3 different batches (experiment performed in triplicate) were recycled into the feed tank to maintain a constant concentration of the feed. Skim milk temperature was maintained at $35^{\circ} \mathrm{C}$ because it was demonstrated that refrigeration temperature or temperatures higher than $50^{\circ} \mathrm{C}$ affect protein structure modifications generated by HHP (Voigt et al., 2015; Ng et al., 2016). The permeate flux was measured at TMP from 76 to $616 \mathrm{kPa}$ at a constant retentate recirculation rate of $360 \mathrm{~L} / \mathrm{h} \cdot \mathrm{m}^{2}$. Typical values in the literature ranged from 34,200 (Green et al., 1981) to $344.4 \mathrm{~L} / \mathrm{h} \cdot \mathrm{m}^{2}$ (Rinaldoni et al., 2009), but this strongly depends on many factors such as TPM applied, type of membrane used (flat-sheet, spiral wound, and so on), and scale of the filtration sys- tem (Rao Ramachandra et al., 1994a,b; Alvarez et al., 1998; Bouzid et al., 2008). However, value used in this work was quite similar to the one used by Rinaldoni et al. (2009) during milk concentration by laboratoryscale UF system. Crossflow velocity was calculated as $0.62 \mathrm{~m} . \mathrm{s}^{-1}$. Each pressure level was maintained for 10 min until a stable flux value was reached. At the end of the recycle mode experiments, critical $\left(\mathbf{J}_{\text {crit }}\right)$ and limiting $\left(\mathbf{J}_{\text {lim }}\right)$ fluxes were determined for nonpressurized and pressure-treated skim milk at 300 and $600 \mathrm{MPa}$. Critical flux is defined as the lowest flux that creates an irreversible deposit on the membrane (Espinasse et al., 2002) and limiting flux is defined as the maximum stationary permeate flux that can be reached when increasing transmembrane pressure (Bacchin et al., 2006).

Concentration Mode. Concentration experiments were performed in batch mode, with simultaneous retentate recycling and permeate removal. The operating parameters of the concentration mode were determined from the $\mathrm{J}_{\text {crit }}$ and $\mathrm{J}_{\text {lim }}$ obtained from total recycle mode experiments. As mentioned for the total recirculation mode, the temperature of the feed was maintained at $35^{\circ} \mathrm{C}$, whereas the duration of the concentration experiments was fixed at $140 \mathrm{~min}$ for pressure-treated milk and 130 min for control milk because it was not possible to recover permeate after $130 \mathrm{~min}$ for control milk due to drastic fouling. The crossflow velocity $(0.62$ $\left.\mathrm{m} \cdot \mathrm{s}^{-1}\right)$, the retentate recirculation rate $\left(360 \mathrm{~L} / \mathrm{h} \cdot \mathrm{m}^{2}\right)$ and the TMP (345 kPa) were kept constant throughout the concentration mode experiments. The permeate fluxes were calculated as a function of time. At the end of the concentration mode experiments, the volume concentration factor obtained for each sample (control and pressurized skim milk) was determined, retentates and permeates of control and pressurized samples were recovered and stored at $4^{\circ} \mathrm{C}$ until analysis, and the UF system was rinsed with demineralized water for permeate flux measurement. Finally, membranes were recovered for fouling characterization.

Rejection Coefficient. The total protein, casein, and whey protein rejection $(\sigma)$ of the $10-\mathrm{kDa}$ polyvinylidene difluoride flat-sheet UF membrane were determined using Equation [1] after control and pressuretreated milk concentration (Razavi et al., 2003):

$$
\sigma=1-\frac{\mathrm{C}_{\mathrm{p}}}{\mathrm{C}_{\mathrm{r}}}
$$

where $\mathrm{C}_{\mathrm{p}}$ and $\mathrm{C}_{\mathrm{r}}$ are the concentrations (\%) of total protein, casein, or whey proteins in the permeate and in the retentate, respectively. 
Protein Concentration Factor. The protein concentration factor (PCF) defines the ratio of the concentration of a protein in the retentate and was obtained using Equation [2] (Hausmann et al., 2013):

$$
\mathrm{PCF}=\frac{\mathrm{TP}_{\text {retentate }}}{\mathrm{TP}_{\text {initial milk }}},
$$

where $\mathrm{TP}_{\text {retentate }}$ is the total protein concentration (\%) of the retentate and $\mathrm{TP}_{\text {initial milk }}$ is the total protein concentration of the initial milk (\%).

\section{Membrane Fouling Evaluation}

Membrane Fouling Characterization. Membrane fouling was characterized after each UF in concentration mode for control and pressurized skim milk by using the resistance-in-series model according to Darcy's law (Gésan-Guiziou et al., 1999; Equation [3]):

$$
\mathrm{J}=\frac{\mathrm{TMP}}{\mu \mathrm{R}},
$$

where $\mathrm{J}$ is the permeate flux $\left(\mathrm{L} \cdot \mathrm{m}^{-2} \cdot \mathrm{h}^{-1}\right), \mu$ is the dynamic viscosity $\left(\mathrm{Pa} \cdot \mathrm{s}^{-1}\right)$, TMP is the transmembrane pressure $(\mathrm{kPa})$, and $\mathrm{R}$ is the membrane hydraulic resistance $\left(\mathrm{m}^{-1}\right)$. In the absence of solutes, $\mathrm{R}$ represents the membrane hydraulic resistance (membrane resistance to permeate, $\mathrm{R}_{\mathrm{M}}$ ), which depends on the porosity, thickness, and average pore diameter of the membrane, as well as solvent (water) viscosity at the filtration temperature (Equation [4]):

$$
\mathrm{R}_{\mathrm{M}}=\frac{\mathrm{TMP}}{\mu_{\mathrm{w}} \mathrm{J}_{\mathrm{w}}}
$$

where $J_{w}$ is the initial water permeate flux $\left(\mathrm{L} \cdot \mathrm{m}^{-2} \cdot \mathrm{h}^{-1}\right)$ and $\mu_{\mathrm{w}}$ is the dynamic viscosity of water $\left(0.55 \times 10^{-3}\right.$ $\left.\mathrm{Pa} \cdot \mathrm{s}^{-1}\right)$ at $20^{\circ} \mathrm{C}$. For filtration of a complex solution, the total membrane resistance $\left(\mathrm{R}_{\mathrm{T}}\right)$ is obtained using Equation [5]:

$$
\mathrm{R}_{\mathrm{T}}=\mathrm{R}_{\mathrm{M}}+\mathrm{R}_{\mathrm{IR}}+\mathrm{R}_{\mathrm{REV}},
$$

where $\mathrm{R}_{\mathrm{IR}}$ is the hydraulic resistance corresponding to the irreversible fouling phase and $R_{\mathrm{REV}}$ is the hydraulic resistance due to reversible phenomena (concentration polarization, reversible deposit, or both). Each resistance can be calculated from Equations [6] and [7]:

$$
\mathrm{R}_{\mathrm{IR}}=\frac{\mathrm{TMP}}{\mu_{\mathrm{w}} \mathrm{J}_{\mathrm{w}^{\prime}}}-\mathrm{R}_{\mathrm{M}},
$$

$$
\mathrm{R}_{\mathrm{REV}}=\frac{\mathrm{TMP}}{\mu_{\mathrm{w}} \mathrm{J}_{\mathrm{w}}{ }^{\prime \prime}}-\mathrm{R}_{\mathrm{M}}-\mathrm{R}_{\mathrm{IR}}
$$

where $J_{\mathrm{w}^{\prime}}$ and $\mathrm{J}_{\mathrm{w}^{\prime \prime}}$ are the final water permeate flux $\left(\mathrm{L} \cdot \mathrm{m}^{-2} \cdot \mathrm{h}^{-1}\right)$ after and before the rinsing step of the membrane, respectively.

Membrane Fouling Analysis. Ultrafiltration membranes used for control and pressurized skim milk concentration were recovered after UF system rinsing. A clean spatula was used to gently scrub the membrane to recover the fouling-layer material deposited on the membrane surface. The fouling material was collected in a plastic tube, diluted with $10 \mathrm{~mL}$ of deionized water, and vortexed for approximately 5 min. Finally, the solution was characterized by SDS-PAGE. This method does not ensure that all proteins are desorbed from the UF membrane, and as mentioned by Tan et al. (2014), these fractions represented weakly attached membrane foulants.

\section{Analyses}

Particle Size Analysis. The effect of HHP on casein micelle size was determined by photon correlation spectroscopy using a Malvern Zetasizer (Malvern Instruments Ltd., Malvern, Worcestershire, UK; Huppertz et al., 2002). Pressure-treated (300 and $600 \mathrm{MPa}$ ) and control skim milk samples were diluted with deionized water to a final concentration of $1 \%$ ( $\mathrm{vol} / \mathrm{vol})$. The light scattering was detected at a $173^{\circ}$ angle at $25^{\circ} \mathrm{C}$. Analyses were performed in triplicate.

Separation of the Soluble and Micellar Phases of Milk. The soluble and the micellar phases of milk were separated according to the protocol of Huppertz et al. (2004). Briefly, pressurized and control milk samples were acidified to $\mathrm{pH} 4.6$ with a $6 \mathrm{M} \mathrm{HCl}$ solution and centrifuged at $15,550 \times g$ for $25 \mathrm{~min}$ at $20^{\circ} \mathrm{C}$. The supernatant, containing nonsedimentable whey proteins, was carefully removed and stored at $4^{\circ} \mathrm{C}$ for further analysis.

Protein Profile Analysis by SDS-PAGE. The level of proteins in the supernatants of pressurized and control milk samples were evaluated by SDS-PAGE. Electrophoresis was performed using Bio-Rad miniprotean TGX precast gels (Bio-Rad, Hercules, CA) containing $12 \%$ acrylamide. Samples were diluted 1:9 with deionized water. Twenty microliters of this mixture was added to $1 \mu \mathrm{L}$ of $\beta$-mercaptoethanol and 19 $\mu \mathrm{L}$ of $2 \times$ Laemmli sample buffer (prepared with 65.8 $\mathrm{m} M$ Tris $\mathrm{HCl}, \mathrm{pH} 6.8,2.1 \%$ SDS, $26.3 \%$ [wt/vol] glycerol, $0.01 \%$ bromophenol blue) and heated for $5 \mathrm{~min}$ at $100^{\circ} \mathrm{C}$. Two molecular weight markers were used: Precision Plus Protein All Blue Standards (Bio-Rad) 
and a milk protein standard consisting of a mixture of pure milk proteins (BSA, IgG, $\beta-\mathrm{CN}, \alpha-\mathrm{CN}, \kappa-\mathrm{CN}$, $\beta$-LG, and $\alpha$-LA from Sigma-Aldrich, St. Louis, MO) produced in the same proportion as milk. The running buffer was prepared by adding $100 \mathrm{~mL}$ of $10 \times$ Tris/ glycine/SDS buffer to $900 \mathrm{~mL}$ of deionized water. All samples were loaded into the gel wells and migrated at $15 \mathrm{~mA}$ until the dye front reached the reference line. After electrophoresis experiments, the gel was stained for 60 min with Coomassie blue solution composed of $1 \mathrm{~g}$ of Coomassie Blue diluted in 10\% acetic acid, $40 \%$ ethanol, and $50 \%$ deionized water solution. Finally, the gel was destained overnight in a $10 \%$ methanol, $10 \%$ acetic acid, and $80 \%$ deionized water solution.

Protein Profile Analysis by HPLC. The nonsedimentable whey protein content was determined by reversed-phase HPLC according to the protocol of Doyen et al. (2012). The $\mathrm{pH}$ 4.6-soluble fractions recovered after skim milk acidification were diluted 1:9 with milliQ water and filtered through a $0.45-\mu \mathrm{m}$ polytetrafluoroethylene (PTFE) membrane (VWR International, Radnor, PA). Samples were injected into an Agilent 110 series system and analyzed with a Luna $5 \mathrm{~mm} \mathrm{C18}$ (Phenomenex, Torrance, CA). Elution was performed with solvent A (trifluoroacetic acid at a final concentration of $0.11 \%[\mathrm{vol} / \mathrm{vol}]$ in water) and solvent B (acetonitrile/HPLC water/trifluoroacetic acid $[90 / 10 / 0.1 \%])$ with a flow rate of $0.2 \mathrm{~mL} \cdot \mathrm{min}^{-1}$. A linear gradient of solvent B was used from 3 to $55 \%$ for $85 \mathrm{~min}$ and from 55 to $100 \%$ for $30 \mathrm{~min}$. Standards of $\beta$-LG (BioPURE) and $\alpha$-LA (BioZzz), supplied by Davisco Foods International Inc. (Eden Prairie, MN), were used to determine major whey protein content in supernatants after pressurization and casein precipitation. Each analysis was carried out in triplicate.

\section{Statistical Analysis}

All experiments were carried out in triplicate. The statistical analysis of the data included an ANOVA for repeated measures with mixed procedure at a $95 \%$ confidence level. All statistical analyses were carried out with SAS software (ver. 9.4, SAS Institute Inc., Cary, NC).

\section{RESULTS}

\section{Modification of Casein Micellar Diameter by HPP}

It was observed that pressurization of milk significantly reduced $(P<0.001)$ the micellar casein size. The mean micelle diameter of nonpressurized skim milk was $193.12 \pm 10.89 \mathrm{~nm}$, whereas it decreased after pressurization to $130.5 \pm 13.01 \mathrm{~nm}$ and $122.62 \pm 16.82$ at
300 and $600 \mathrm{MPa}$, respectively. However, no significant difference was observed between pressurized samples $(P$ $>0.05$; data not shown).

\section{Effect of Pressurization on Whey Protein Solubility}

Figure 1 shows the protein profile of supernatants ( $\mathrm{pH}$ 4.6-soluble fraction) recovered after precipitation of control and pressure-treated skim milk samples. Compared with nontreated milk, the intensities of the bands corresponding to $\beta-\mathrm{LG}$ decreased for both pressurization treatments and more drastically at $600 \mathrm{MPa}$. However, the intensities of the bands corresponding to $\alpha$-LA seems to be similar between nontreated and pressurized samples. To confirm these results, the concentrations of both whey proteins were calculated after reversed-phase HPLC analysis (Table 1). As observed for SDS-PAGE results, the $\alpha$-LA concentration was similar between control and pressurized samples with values of about $0.089 \mathrm{~g}$ (Table 1). Nevertheless, and compared with skim milk control, $\beta$-LG concentration decreased by 28 and $60 \%$ at 300 and $600 \mathrm{MPa}$, respectively. No band corresponding to minor whey proteins (BSA and IgG) was observed for any skim milk sample (control and pressurized) due to their low concentrations. Logically, no casein was observed in milk samples

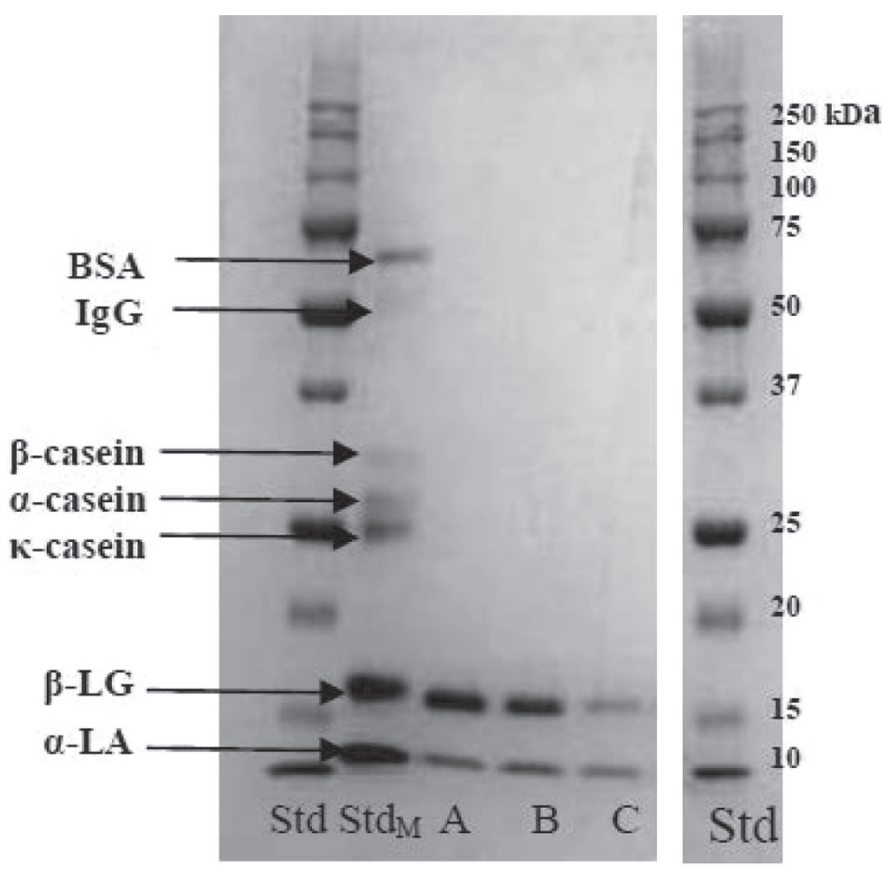

Figure 1. Sodium dodecyl sulfate-PAGE pattern of supernatant ( $\mathrm{pH}$ 4.6-soluble fraction) for nonpressurized milk (A), and milk pressurized at $300 \mathrm{MPa}(\mathrm{B})$ and $600 \mathrm{MPa}(\mathrm{C})$, where Std represents the standard and $\mathrm{Std}_{\mathrm{M}}$ represents the standard composed of the different milk proteins. 
Table 1. Concentration of $\alpha-\mathrm{LA}$ and $\beta$-LG in the supernatants of control and pressurized skim milk samples

\begin{tabular}{lcc}
\hline & \multicolumn{2}{c}{ Concentration $(\mathrm{g} / \mathrm{L})$} \\
\cline { 2 - 3 } Treatment & $\alpha-\mathrm{LA}$ & $\beta-\mathrm{LG}$ \\
\hline Control & $1.46 \pm 0.24^{\mathrm{a}}$ & $5.61 \pm 0.91^{\mathrm{a}}$ \\
$300 \mathrm{MPa}$ & $1.47 \pm 0.39^{\mathrm{a}}$ & $4.02 \pm 0.58^{\mathrm{b}}$ \\
$600 \mathrm{MPa}$ & $1.48 \pm 0.23^{\mathrm{a}}$ & $2.24 \pm 0.43^{\mathrm{c}}$ \\
\hline
\end{tabular}

${ }^{\mathrm{a}-\mathrm{c}} \mathrm{Different}$ letters in the same column indicate a significant difference $(P<0.001, \mathrm{n}=3)$.

because the micellar fraction was precipitated at $\mathrm{pH} 4.6$ before SDS-PAGE analysis (Figure 1).

\section{Ultrafiltration Performance}

Total Recycle Mode. Figure 2 shows the variation of the permeate flux for control and pressurized skim milk during UF in total recirculation mode at a constant flow rate of $360 \mathrm{~L} / \mathrm{h} \cdot \mathrm{m}^{2}$, as a function of the increasing TMP from 76 to $616 \mathrm{kPa}$. The pure water flux increased linearly from 100 to $380 \mathrm{~L} \cdot \mathrm{m}^{-2} \cdot \mathrm{h}^{-1}$ from initial to final TMP (data not shown). The permeate fluxes during UF of control and pressurized samples were largely lower than the pure water flux; consequently, the concentration polarization greatly affected UF performance. Moreover, a significant difference $(P$ $<0.05)$ in permeate flux evolution as a function of TMP was observed between nontreated and pressurized skim milk. For the control milk, permeate flux increased with the TMP from $22.8 \pm 3.5 \mathrm{~L} \cdot \mathrm{m}^{-2} \cdot \mathrm{h}^{-1}$ to $33.6 \pm 4.4$ $\mathrm{L} \cdot \mathrm{m}^{-2} \cdot \mathrm{h}^{-1}$ (about a $50 \%$ increase) between 76 and 616

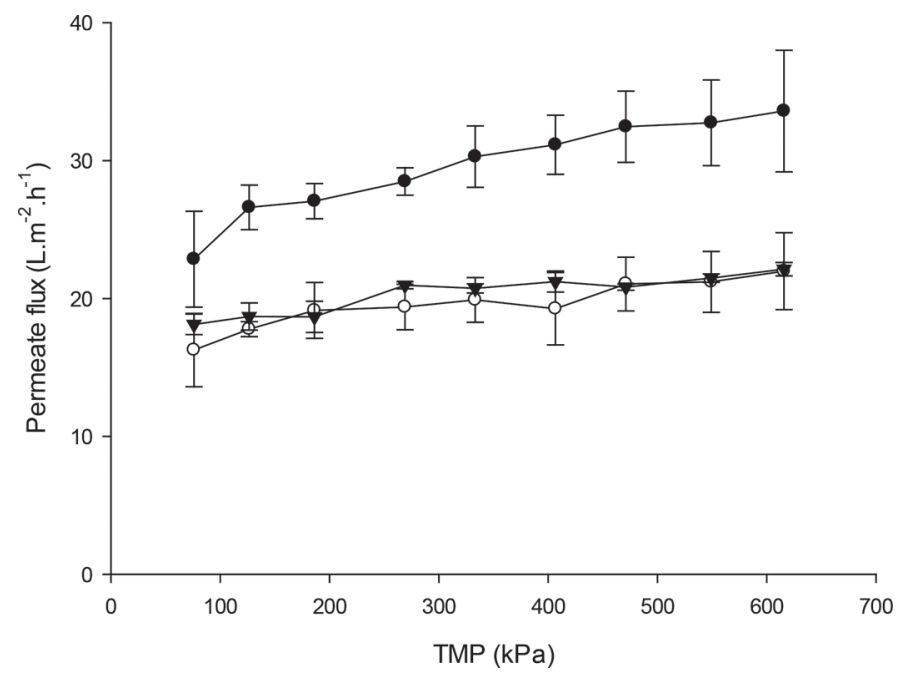

Figure 2. Permeate flux-transmembrane pressure (TMP) relationship for nontreated milk (-) and pressure-treated milk at $300 \mathrm{MPa}$ $(\bigcirc)$ and $600 \mathrm{MPa}(\mathbf{\nabla})$. Data are means of triplicate experiments \pm SD.
Table 2. Evolution of critical and limiting fluxes during total recirculation of control and pressure-treated milk samples

\begin{tabular}{lcc}
\hline Treatment & $\begin{array}{c}\text { Critical flux } \\
\left(\mathrm{L} \cdot \mathrm{m}^{-2} \cdot \mathrm{h}^{-1}\right)\end{array}$ & $\begin{array}{c}\text { Limiting flux } \\
\left(\mathrm{L} \cdot \mathrm{m}^{-2} \cdot \mathrm{h}^{-1}\right)\end{array}$ \\
\hline Control & $28.18 \pm 1.84^{\mathrm{a}}$ & $35.18 \pm 3.18^{\mathrm{a}}$ \\
$300 \mathrm{MPa}$ & $19.61 \pm 2.61^{\mathrm{b}}$ & $23.85 \pm 3.65^{\mathrm{b}}$ \\
$600 \mathrm{MPa}$ & $19.19 \pm 1.08^{\mathrm{b}}$ & $25.99 \pm 0.42^{\mathrm{b}}$ \\
\hline
\end{tabular}

$\overline{\mathrm{a}, \mathrm{b}}$ Different letters in the same column indicate a significant difference $(P<0.05, \mathrm{n}=3)$.

$\mathrm{kPa}$, respectively. Permeate fluxes during recirculation of pressure-treated milks were similar $(P>0.05)$, but drastically lower compared with the control. Indeed, pressurization at 300 and $600 \mathrm{MPa}$ induced a slight increase in permeate flux as a function of TMP with values ranging from $17.2 \pm 1.7 \mathrm{~L} \cdot \mathrm{m}^{-2} \cdot \mathrm{h}^{-1}$ to $20.0 \pm 1.6$ $\mathrm{L} \cdot \mathrm{m}^{-2} \cdot \mathrm{h}^{-1}$ (about an $18 \%$ increase). The permeate fluxtransmembrane pressure relationship (Figure 2) allowed us to determine $\mathrm{J}_{\text {crit }}$ and $\mathrm{J}_{\text {lim }}$ parameters for control and pressurized milk (Table 2). Critical flux was similar ( $P$ $>0.05)$ for the 2 pressurized milks with values of 3.84 $\times 10^{-3}$ and $3.76 \times 10^{-3} \mathrm{~L} \cdot \mathrm{m}^{-2} \cdot \mathrm{h}^{-1}$ at 300 and $600 \mathrm{MPa}$, respectively, but it increased significantly $(P<0.001)$ for untreated milk to a value of $5.52 \times 10^{-3} \mathrm{~L} \cdot \mathrm{m}^{-2} \cdot \mathrm{h}^{-1}$. The control milk had a higher $\mathrm{J}_{\text {lim }}$ than pressurized milk; it decreased by 32 and $26 \%$ at $300 \mathrm{MPa}(P<$ $0.001)$ and at $600 \mathrm{MPa}(P<0.001)$, respectively.

Concentration Mode. To evaluate the effect of pressurization on membrane fouling during concentration mode experiments, TMP was fixed at $345 \mathrm{kPa}$, which corresponds to the $\mathrm{J}_{\text {crit }}$ value for the control and pressure-treated milk calculated after total recirculation mode experiments. At the beginning of UF in concentration mode, initial fluxes were similar for pressure-treated milks $\left(P>0.05 ; 22.4 \mathrm{~L} \cdot \mathrm{m}^{-2} \cdot \mathrm{h}^{-1}\right)$ but lower than control milk $\left(32.9 \mathrm{~L} \cdot \mathrm{m}^{-2} \cdot \mathrm{h}^{-1}\right)$, with a decrease of about $34 \%$ at $300 \mathrm{MPA}$ and $30 \%$ at $600 \mathrm{MPa}$ (Figure 3). However, during the concentration step, the decrease in permeate flux was similar $(33.5 \pm 2.50 \%)$ for pressure-treated milks but higher for nonpressurized milk (59.3\%), but whatever the condition tested, permeate fluxes were similar at the end of UF $(P>$ $0.05)$. Nevertheless, in practice, a factor of $4 \times$ or $6 \times$ is generally obtained during skim milk UF, whereas it ranged from $2 \times$ to $3 \times$ in the present work as a function of treatment applied. In this context, and because a longer filtration duration is necessary to reach a protein concentration factor of $4 \times$ or $6 \times$, it might be possible the flux of the pressure-treated skim milk would be higher than the control milk.

The differences observed during UF experiments for permeate flux significantly affected $(P<0.05)$ the 
Table 3. Protein content of retentates and permeates, rejection coefficients, and concentration factors obtained after UF concentration of control and pressure-treated skim milk at 300 and $600 \mathrm{MPa}$

\begin{tabular}{|c|c|c|c|c|c|c|c|}
\hline Item $^{1}$ & $\begin{array}{l}\text { Initial } \\
\text { milk }^{2}\end{array}$ & \multicolumn{2}{|c|}{ Control } & \multicolumn{2}{|c|}{$300 \mathrm{MPa}$} & \multicolumn{2}{|c|}{$600 \mathrm{MPa}$} \\
\hline $\mathrm{TN}(\%)$ & $4.17 \pm 0.67$ & $11.99 \pm 2.07^{\mathrm{a}}$ & $0.17 \pm 0.06^{\mathrm{a}}$ & $7.76 \pm 2.37^{\mathrm{b}}$ & $0.15 \pm 0.09^{\mathrm{a}}$ & $7.99 \pm 1.21^{\mathrm{b}}$ & $0.15 \pm 0.04^{\mathrm{a}}$ \\
\hline NPN $(\%)$ & $0.19 \pm 0.02$ & $0.21 \pm 0.03^{\mathrm{a}}$ & $0.16 \pm 0.03^{\mathrm{a}}$ & $0.23 \pm 0.03^{\mathrm{a}}$ & $0.16 \pm 0.02^{\mathrm{a}}$ & $0.24 \pm 0.04^{\mathrm{a}}$ & $0.13 \pm 0.06^{\mathrm{a}}$ \\
\hline $\mathrm{TP}(\%)$ & $3.89 \pm 0.52$ & $11.78 \pm 1.04^{\mathrm{a}}$ & $0.01 \pm 0.07^{\mathrm{a}}$ & $7.53 \pm 1.59^{\mathrm{b}}$ & $0.01 \pm 0.10^{\mathrm{a}}$ & $7.75 \pm 0.86^{\mathrm{b}}$ & $0.02 \pm 0.08^{\mathrm{a}}$ \\
\hline $\mathrm{CN}(\%)$ & $3.43 \pm 0.51$ & $9.71 \pm 0.96^{\mathrm{a}}$ & $0.13 \pm 0.07^{\mathrm{a}}$ & $6.78 \pm 1.54^{\mathrm{b}}$ & $0.18 \pm 0.10^{\mathrm{a}}$ & $6.51 \pm 0.77^{\mathrm{b}}$ & $0.15 \pm 0.08^{\mathrm{a}}$ \\
\hline$\sigma \mathrm{CN}$ & & \multicolumn{2}{|c|}{$0.995 \pm 0.003^{\mathrm{a}}$} & \multicolumn{2}{|c|}{$0.980 \pm 0.029^{\mathrm{a}}$} & \multicolumn{2}{|c|}{$0.996 \pm 0.004^{\mathrm{a}}$} \\
\hline$\sigma \mathrm{SP}$ & & \multicolumn{2}{|c|}{$0.983 \pm 0.015^{\mathrm{a}}$} & \multicolumn{2}{|c|}{$0.983 \pm 0.015^{\mathrm{a}}$} & \multicolumn{2}{|c|}{$0.941 \pm 0.038^{\mathrm{b}}$} \\
\hline $\mathrm{PCF}$ & $1.00^{\mathrm{a}}$ & \multicolumn{2}{|c|}{$3.03 \pm 0.17^{\mathrm{c}}$} & \multicolumn{2}{|c|}{$1.93 \pm 0.10^{\mathrm{b}}$} & \multicolumn{2}{|c|}{$1.99 \pm 0.35^{\mathrm{b}}$} \\
\hline
\end{tabular}

${ }^{\mathrm{a}-c}$ Different letters in the same row indicate significant differences $(P<0.05, \mathrm{n}=3)$ between retentates or permeates.

${ }^{1} \mathrm{TN}=$ total nitrogen $\times 6.38 ; \mathrm{NCN}=$ noncasein nitrogen $\times 6.38 ; \mathrm{NPN}=$ nonprotein nitrogen $\times 6.38 ; \mathrm{TP}=$ true protein $(\mathrm{TN}-\mathrm{NPN}) ; \mathrm{CN}=$ casein $(\mathrm{TN}-\mathrm{NCN}) ; \mathrm{SP}=$ serum proteins $(\mathrm{TP}-\mathrm{CN}) ; \sigma=$ rejection coefficient; $\mathrm{PCF}=$ protein concentration factor.

${ }^{2}$ The composition of initial milks was not compared with retentate and permeate compositions.

protein concentration factor obtained at the end of UF. Whereas no significant difference $(P<0.05)$ was observed between both pressurized conditions (Table 3 ), the protein concentration factor was significantly higher during UF of control milk compared with UF of pressurized milk $(P<0.05)$ with values of $3.03 \pm$ 0.17 (control), $1.93 \pm 0.10(300 \mathrm{MPa})$, and $1.99 \pm$ 0.35 (600 MPa; Table 3). These differences affected only the retentate compositions because true protein, casein, and whey protein concentrations were obviously higher for the control milk retentate compared with those measured after UF of pressurized milks (Table 3). Rejection coefficients $(\sigma)$ of true proteins, caseins, and serum proteins were similar for all conditions except

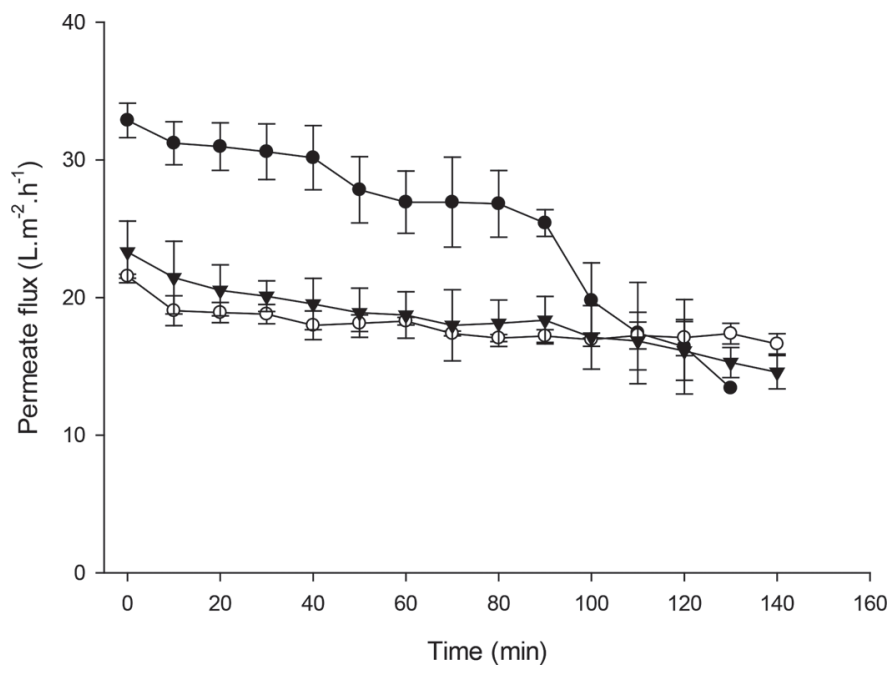

Figure 3. Evolution of permeate flux for unpressurized milk and milk treated at $300 \mathrm{MPa}(\mathrm{O})$ and $600 \mathrm{MPa}(\mathbf{\nabla})$. Data are means of triplicate experiments \pm SD. for $600 \mathrm{MPa}$, where $\sigma$ of serum proteins was lower $(P$ $<0.05)$ compared with the control and $300 \mathrm{MPa}$ conditions (Table 3 ).

Fouling Resistances. Table 4 shows the membrane resistance, RM, as well as reversible, irreversible, and total resistance calculated after concentration of unpressurized and pressure-treated milk at 300 and 600 MPa. As expected, RM was similar $(P>0.05)$ whatever the condition tested, with a mean value of $0.59 \pm$ $0.03 \times 1,010 \mathrm{~m}^{-1}$ (Table 4). The reversible resistance was also similar for all tested conditions $(P>0.05)$ with a mean value of $7.11 \pm 1.14 \times 1,010 \mathrm{~m}^{-1}$, but irreversible fouling was significantly higher at $600 \mathrm{MPa}$ $(P<0.05)$ compared with other conditions. Overall, total resistance values were similar for control and 300 $\mathrm{MPa}$ conditions, but higher at $600 \mathrm{MPa}$.

Characterization of Fouling Material. The protein profile of the fouling layer recovered from membranes after UF was analyzed by SDS-PAGE (Figure 4). Protein bands were only observed following UF of pressurized milk, but bands were more intense for the $600 \mathrm{MPa}$ treatment, suggesting that the fouling layer was more important at $600 \mathrm{MPa}$ compared with 300 $\mathrm{MPa}$ and control skim milk. After UF of milk treated at $300 \mathrm{MPa}$, the major proteins recovered were caseins, but a low amount of $\beta$-LG was also noted. Caseins and $\beta$-LG were dominant following UF of the $600 \mathrm{MPa}-$ treated milk, but traces of $\alpha-\mathrm{LA}$, IgG, and other aggregates were also recovered (Figure 4).

\section{DISCUSSION}

The purpose of this study was to evaluate UF performance during the concentration of skim milk treated by HHP processing. Our results provided the first evidence 
Table 4. Hydraulic resistances of UF membranes used for concentration of nontreated and pressure-treated skim milk

\begin{tabular}{lcccc}
\hline & \multicolumn{4}{c}{ Resistance $\left(1,010 \mathrm{~m}^{-1}\right)$} \\
\cline { 2 - 4 } Condition & Membrane & Reversible & Irreversible & Total \\
\hline Control & $0.57 \pm 0.05^{\mathrm{a}}$ & $6.45 \pm 2.34^{\mathrm{a}}$ & $2.21 \pm 1.05^{\mathrm{a}}$ & $9.22 \pm 1.77^{\mathrm{a}}$ \\
$300 \mathrm{MPa}$ & $0.59 \pm 0.16^{\mathrm{a}}$ & $6.46 \pm 2.07^{\mathrm{a}}$ & $2.11 \pm 0.44^{\mathrm{a}}$ & $9.16 \pm 2.03^{\mathrm{a}}$ \\
$600 \mathrm{MPa}$ & $0.62 \pm 0.11^{\mathrm{a}}$ & $8.43 \pm 3.21^{\mathrm{a}}$ & $4.14 \pm 1.73^{\mathrm{b}}$ & $13.2 \pm 4.01^{\mathrm{b}}$ \\
\hline
\end{tabular}

$\overline{\mathrm{a}, \mathrm{b}}$ Different letters in the same column indicate significant differences $(P<0.05, \mathrm{n}=3)$.

that pressurization of milk at 300 and $600 \mathrm{MPa}$ over 5 min negatively affected permeate flux and membrane fouling in total recirculation or concentration mode. These negative effects were related to the amount of pressure applied to skim milk, the duration of HPP treatment, and consequently, to the modification of milk protein structure (size, denaturation, and aggregation).

\section{Effect of HHP on Milk Protein}

It was observed that $\mathrm{HHP}$ at 300 and $600 \mathrm{MPa}$ for 5 min decreased casein size and induced modifications of whey protein content in the $\mathrm{pH} 4.6$-soluble fraction. These results are consistent with previously published reports demonstrating that pressurization induced disintegration of casein and denaturation/aggregation of whey proteins (Huppertz et al., 2006a). In the casein fraction, micelle size reduction is related to the pressurization level, treatment time, and temperature of the milk during HPP (Huppertz et al., 2006a). Indeed, pressurization of raw skim milk at 400 and $600 \mathrm{MPa}$ at $4^{\circ} \mathrm{C}$ resulted in complete destabilization of casein micelles, with decreases in size from $150-200 \mathrm{~nm}$ to 40 $\mathrm{nm}$ at $600 \mathrm{MPa}$ for $15 \mathrm{~min}$ (Needs et al., 2000). Huppertz et al. (2004) observed that hydrostatic pressure treatments in the range of 300 to $800 \mathrm{MPa}$ irreversibly reduced casein micelle size by $50 \%$ compared with nontreated milk, even after subsequent storage for 24 or $48 \mathrm{~h}$ at 5 or $20^{\circ} \mathrm{C}$. Anema (2007) showed that casein micelle size decreased drastically after pressurization of reconstituted skim milk (12\% TS) at 300 and 600 $\mathrm{MPa}$ at $20^{\circ} \mathrm{C}$. Other studies demonstrated that casein micelles were completely disrupted at $400 \mathrm{MPa}$ because higher pressurization treatments did not reduce micellar size (Huppertz et al., 2006a; Bravo et al., 2015). The decrease in casein size is explained by the disruption of hydrophobic and electrostatic interactions in casein micelles, and the solubilization of colloidal calcium phosphate (Huppertz et al., 2002). For whey proteins, our results showed that the $\beta$-LG content in the acid-soluble fraction decreased compared with $\alpha$-LA concentration.
These results are related to the whey protein structure and their sensitivity to HPP. Indeed, $\beta-\mathrm{LG}$ is the most sensitive protein to HHP, whereas $\alpha-\mathrm{LA}$ are known to be resistant to denaturation up to $400 \mathrm{MPa}$ (Huppertz et al., 2002). Isostatic pressure collapses the inner calyx of $\beta$-LG and exposes reactive free thiol groups that lead to the formation of intra- and intermolecular disulfide bonds. Consequently, $\beta$-LG interactions occurred with $\kappa-\mathrm{CN}, \beta-\mathrm{LG}, \alpha-\mathrm{LA}$, and possibly with $\alpha_{\mathrm{S}^{2}} \mathrm{CN}$ (Huppertz et al., 2006a). As observed by Huppertz et al. (2004), our results showed that $\beta$-LG mainly interacted with casein micelles because a substantial loss of $\beta$-LG was observed in the supernatant after casein precipitation at pH 4.6 (Huppertz et al., 2004).

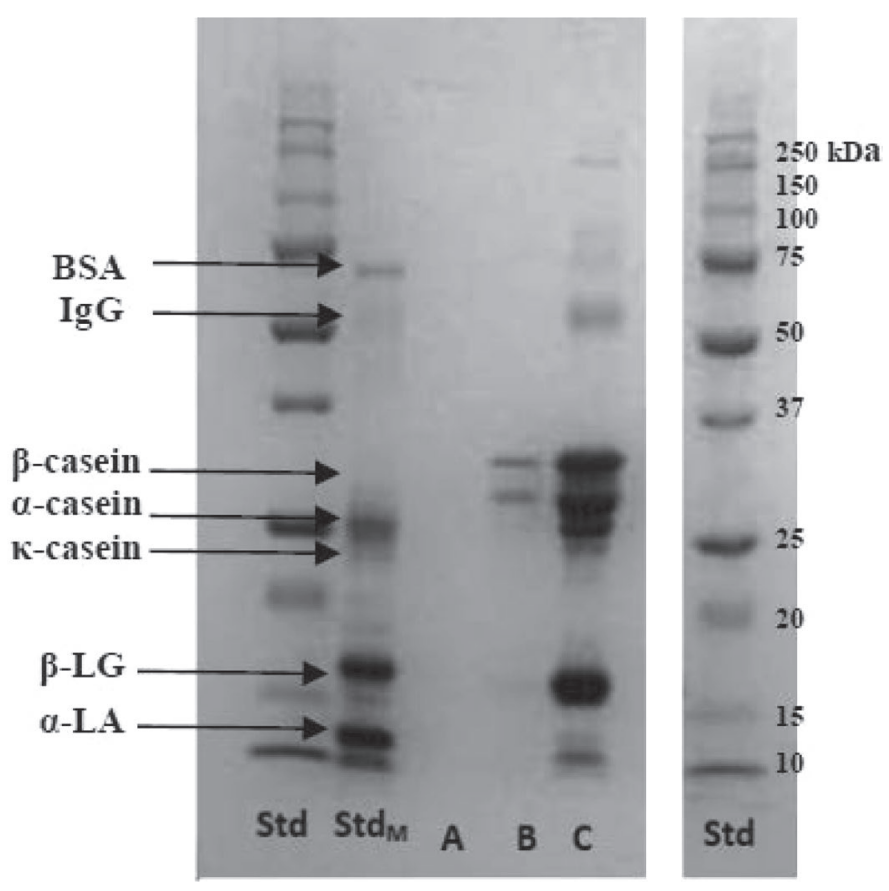

Figure 4. Sodium dodecyl sulfate-PAGE pattern of fouling layer recovered after UF for nonpressurized milk (A), and milk pressurized at $300 \mathrm{MPa}(\mathrm{B})$ and $600 \mathrm{MPa}(\mathrm{C})$, where Std represents the standard and $\mathrm{Std}_{\mathrm{M}}$ represents the standard composed of the different milk proteins. 


\section{Time Dependence Between Permeate Flux and Transmembrane Pressure}

In total recirculation mode, only variations of TMP and pressure treatments applied to the skim milk negatively affected filtration performance. Our results clearly demonstrated that the performance of UF was drastically reduced during total recirculation of pressure-treated milk. Indeed, permeate fluxes were lower for pressurized milk at the beginning of and throughout UF experiments. As explained by other studies on UF of nonpressurized milks, the lower permeate fluxes observed in total recirculation mode were due to a larger accumulation of milk components in the polarization layer. This induced membrane fouling, which drastically increased the resistance to permeate.

Besides permeate flux, $\mathrm{J}_{\text {crit }}$ and $\mathrm{J}_{\mathrm{lim}}$ are good indicators of UF performance. Critical flux is the lowest flux that creates irreversible fouling on a filtration membrane and was obtained when a deviation from linearity was observed in the TMP-flux relationship. Limiting flux is the highest flux obtained as a function of TMP applied. Different phenomena explain the appearance of critical and limiting flux, such as adsorption of milk components at the surface of or in the membrane, or formation of a cake at the membrane surface (Chen et al., 1997; Li et al., 1998; Huisman et al., 1999). Consequently, differences observed in $\mathrm{J}_{\text {crit }}$ and $\mathrm{J}_{\mathrm{lim}}$ demonstrated that fouling of the UF membrane and its saturation by milk components appeared earlier for pressure-treated milk compared with control milk.

Different hypotheses could explain the differences observed between control and pressure-treated milk during filtration. The first is the effect of HPP on casein size, and serum protein denaturation and aggregation. Indeed, for conventional pasteurized skim milk, Bouzid et al. (2008) showed that casein size had a drastic effect on limiting and critical flux during filtration. Specifically, small casein particles of less than $80 \mathrm{~nm}$ diameter generated a smaller limiting TMP. In the case of serum proteins, pressurization of milk induced whey protein denaturation and aggregation. Specifically, $\beta$-LG, the whey protein most sensitive to hydrostatic pressure, forms aggregates with casein, specifically $\kappa$-CN or $\alpha_{S_{2}-} \mathrm{CN}$. Moreover, aggregation of $\beta$-LG with $\alpha$-LA occurred due to sulfhydryl-disulfide exchange reactions (Kolakowski et al., 2001; Huppertz et al., 2004; He et al., 2011). Several studies demonstrated that aggregation of milk proteins are responsible for membrane fouling because the elimination of large aggregates by pre-filtration or ultrasonic treatments improved filtration performance (Hilal et al., 2005; Mohammad et al., 2012; Ng et al., 2016). The results could be explained by the effect of HPP on calcium phosphate solubilization during pressurization. Indeed, during pressurization, caseins are disrupted and calcium phosphate largely solubilized. It was demonstrated that interactions between membrane material and phosphates, calcium, and organic molecules of whey or milk occurred during filtration and improved fouling (Bouzid et al., 2008). Specifically, calcium ion facilitates protein-protein and protein-membrane interactions (Jimenez-Lopez et al., 2008).

\section{Evolution of Permeate Flux During Skim Milk Concentration}

Experiments performed in concentration mode confirmed that pressure-treated milk negatively affected permeate flux. It was observed that permeate flux for pressure-treated milk was drastically lower than control milk, except at the end of filtration where all permeate flux values were similar. As mentioned for total recirculation mode, the distinctive flux decrease observed between control and milk treated by HHP can be explained by the effect of HPP on protein structure modification and calcium phosphate solubilization, and consequently, on both concentration polarization and protein gel and cake formation at the membrane surface or in membrane pores. Retentate compositions of true protein, casein, and serum protein were obviously largely different between control and pressure-treated milks for the same UF duration because permeate flux, and consequently, protein concentration factors were higher for control milk. Rejection coefficient values for true protein, caseins, and serum proteins agreed with previous work performed on UF of conventional pasteurized milk, except for milk treated at $600 \mathrm{MPa}$ (Dushkova and Dinkov, 2005). Indeed, the lower serum protein content found by Dushkova and Dinkov in the retentates of $600 \mathrm{MPa}$-treated milk, compared with other conditions, is quite surprising because no difference in serum protein concentration was observed in permeates recovered for this study. During UF of the milk treated at $600 \mathrm{MPa}$, it could be hypothesized that a higher rate of serum protein fouling of the UF membrane decreased the concentration of whey proteins in the retentate, and consequently, decreased the rejection coefficient.

\section{Membrane Fouling Evaluation}

Hydraulic resistances between control and pressuretreated milks were similar except for irreversible resistance, which was higher for the $600 \mathrm{MPa}$ condition. Irreversible fouling is a complex phenomenon defined 
as the membrane resistance remaining after the rinsing step. In particular, irreversible resistance after skim milk UF and microfiltration is explained by the deposition and adsorption of milk particles at the membrane surface as well as plugging internal pores. Irreversible resistance depends on filtration parameters, membrane material, and initial feed composition. Because filtration parameters and membrane materials were similar between experiments, the increase in irreversible resistance for the $600 \mathrm{MPa}$ condition is explained by the modification of milk components induced by HPP. This hypothesis was confirmed by the protein profiles obtained by SDS-PAGE. No protein was detected in the scrubbed fouling layer of membranes used for UF of control milk, suggesting that proteins were not irreversibly attached to the membrane. Conversely, structural modifications induced by HPP at 300 and $600 \mathrm{MPa}$ improved irreversible fouling at membrane surface. With milk treated at $300 \mathrm{MPa}$, mostly caseins were detected on membranes, whereas milk treated at $600 \mathrm{MPa}$ resulted in a larger amount of both soluble and colloidal proteins. Previous studies demonstrated that the protein fraction represents the major fouling material during membrane separation due to protein-protein and protein-membrane interactions. Specifically, caseins were identified as the major proteins involved in the fouling phenomenon during skim milk UF (Rabiller-Baudry et al., 2005; Bouzid et al., 2008). However, Tong et al. (1988) found that fouling during UF of whole milk was due to $\alpha$-LA and $\beta$-LG because they accounted for $95 \%$ of the protein fouling at the membrane surface. Other studies demonstrated that whey protein aggregates, especially $\beta$-LG aggregates, accelerate membrane fouling during UF of whey (Lee and Merson, 1975; Steinhauer et al., 2015). Consequently, the increase in fouling at the membrane surface observed for pressure-treated milk, especially milk treated at $600 \mathrm{MPa}$, is related to protein structure modifications during HHP of milk, particularly the formation of whey protein aggregates and casein- $\beta$-LG aggregates. However, because pressurization induced the solubilization of colloidal calcium phosphate, these salts may have participated in the increase in membrane fouling (Hanemaaijer et al., 1989).

\section{CONCLUSIONS}

Our results demonstrate that HPP treatment of skim milk drastically decreased UF performance. Indeed, filtration of a pressure-treated milk at 300 and $600 \mathrm{MPa}$ over 5 min produced large decreases in the permeate flux and increased membrane fouling. Critical and limiting fluxes were lower for pressure-treated milk compared with control milk and the protein concentra- tion factor achieved for the same time of filtration was lower for pressure-treated milk. Irreversible membrane fouling was observed at $600 \mathrm{MPa}$ and characterization of the fouling layer indicated that caseins and $\beta-L G$ were involved in permeate flux decrease.

\section{ACKNOWLEDGMENTS}

The authors thank Diane Gagnon (Laval University) for technical support. Davisco Foods International Inc. (Eden Prairie, MN) is acknowledged for providing whey protein standards. The financial support of the MAPAQ (Ministère de l'Agriculture des Pêcheries et de l'Alimentation du Québec, Canada) is gratefully recognized.

\section{REFERENCES}

Alvarez, F., M. Argüello, M. Cabero, F. A. Riera, R. Alavarez, J. R. Iglesias, and J. Granda. 1998. Fermentation of concentrated skim milk. Effects of different protein/lactose ratios obtained by ultrafiltration-diafiltration. J. Sci. Food Agric. 76:10-16.

Anema, S. G. 2007. Effect of milk solids concentration on whey protein denaturation, particle size changes and solubilization of casein in high-pressure-treated skim milk. Int. Dairy J. 18:228-235. https:// doi.org/10.1016/j.idairyj.2007.08.009.

Bacchin, P., P. Aimar, and R. W. Field. 2006. Critical and sustainable fluxes: Theory, experiments and applications. J. Membr. Sci. 281:42-69. https://doi.org/10.1016/j.memsci.2006.04.014.

Balasubramaniam, V. M., G. V. Barbosa-Cánovas, and H. L. M. Lelieveld. 2016. High pressure processing of food. G. V. Barbosa-Cánovas, ed. Springer. https://doi.org/10.1007/978-1-4939-3234-4.

Bégoin, L., M. Rabiller-Baudry, B. Chaufer, C. Faille, P. BlanpainAvet, T. Bénézech, and T. Doneva. 2006. Methodology of analysis of a spiral-wound module. Application to PES membrane for ultrafiltration of skimmed milk. Desalination 192:40-53.

Bouzid, H., M. Rabiller-Baudry, L. Paugam, F. Rousseau, Z. Derriche, and N. E. Bettahar. 2008. Impact of zeta potential and size of caseins as precursors of fouling deposit on limiting and critical fluxes in spiral ultrafiltration of modified skim milks. J. Membr. Sci. 314:67-75. https://doi.org/10.1016/j.memsci.2008.01.028.

Bravo, F. I., X. Felipe, R. López-Fandiño, and E. Molina. 2015. Skim milk protein distribution as a result of very high hydrostatic pressure. Food Res. Int. 72:74-79. https://doi.org/10.1016/j. foodres.2015.03.014.

Chawla, R., G. R. Patil, and A. K. Singh. 2011. High hydrostatic pressure technology in dairy processing: A review. J. Food Sci. Technol. 48:260-268. https://doi.org/10.1007/s13197-010-0180-4.

Chen, V., G. Fane, S. Madaeni, and I. G. Wenten. 1997. Particle deposition during membrane filtration of colloids: Transition between concentration polarization and cake formation. J. Membr. Sci. 125:109-122. https://doi.org/10.1016/S0376-7388(96)00187-1.

Considine, T., H. a. Patel, S. G. Anema, H. Singh, and L. K. Creamer. 2007a. Interactions of milk proteins during heat and high hydrostatic pressure treatments-A review. Innov. Food Sci. Emerg. Technol. 8:1-23. https://doi.org/10.1016/j.ifset.2006.08.003.

Considine, T., H. a. Patel, H. Singh, and L. K. Creamer. 2007b. Influence of binding conjugated linoleic acid and myristic acid on the heat- and high-pressure-induced unfolding and aggregation of $\beta$-lactoglobulin B. Food Chem. 102:1270-1280. https://doi. org/10.1016/j.foodchem.2006.07.022.

Daufin, G., U. Merin, J. P. Labbé, A. Quémerais, and F. L. Kerhervé. 1991. Cleaning of inorganic membranes after whey and milk ultrafiltration. Biotechnol. Bioeng. 38:82-89. 
Doyen, A., L. Saucier, L. Beaulieu, Y. Pouliot, and L. Bazinet. 2012. Electroseparation of an antibacterial peptide fraction from snow crab by-products hydrolysate by electrodialysis with ultrafiltration membranes. Food Chem. 132:1177-1184. https://doi. org/10.1016/j.foodchem.2011.11.059.

Dushkova, M. a., and K. T. Dinkov. 2005. Investigation of process characteristics and of principal components of ultrafiltration retentates. Biotechnol. Biotechnol. Equip. 19:179-182. https://doi.org/ 10.1080/13102818.2005.10817212.

Espinasse, B., P. Bacchin, and P. Aimar. 2002. On an experimental method to measure critical flux in ultrafiltration. Desalination 146:91-96. https://doi.org/10.1016/S0011-9164(02)00495-2.

Gesan-Guiziou, G. 2012. Concentrated milk and powders. Pages 208224 in Membrane Processing: Dairy and Beverage Applications. A. Y. Tamime, ed. Blackwell Publishing Ltd., Oxford, UK. https:// doi.org/10.1002/9781118457009.ch10.

Gésan-Guiziou, G., E. Boyaval, and G. Daufin. 1999. Critical stability conditions in crossflow microfiltration of skimmed milk: Transition to irreversible deposition. J. Membr. Sci. 158:211-222. https://doi. org/10.1016/S0376-7388(99)00017-4.

Green, L. M., A. F. Glover, E. M. W. Scurlock, R. J. Marshall, and D. S. Hatfield. 1981. Effect of use of milk concentrated by ultrafiltration on the manufacture and ripening of Cheddar cheese. J. Dairy Res. 48:333-341. https://doi.org/10.1017/S0022029900021762.

Hanemaaijer, J. H., T. Robbertsen, T. van den Boomgaard, and J. W. Gunnink. 1989. Fouling of ultrafiltration membranes. The role of protein adsorption and salt precipitation. J. Membr. Sci. 40:199217. https://doi.org/10.1016/0376-7388(89)89005-2.

Hausmann, A., M. C. Duke, and T. Demmer. 2013. Principles of membrane filtration. Pages 17-51 in Membrane Processing: Dairy and Beverage Applications. A. Y. Tamime, ed. Blackwell Publishing Ltd., Oxford, UK. https://doi.org/10.1002/9781118457009.ch2.

He, J. S., S. Zhu, T. H. Mu, Y. Yu, J. Li, and N. Azuma. 2011. A casein inhibits the pressure-induced aggregation of B-lactoglobulin through its molecular chaperone-like properties. Food Hydrocoll. 25:1581-1586. https://doi.org/10.1016/j.foodhyd.2011.01.008.

Hilal, N., O. O. Ogunbiyi, N. J. Miles, and R. Nigmatullin. 2005. Methods employed for control of fouling in MF and UF membranes: A comprehensive review. Sep. Sci. Technol. 40:1957-2005. https://doi.org/10.1081/SS-200068409.

Huffman, L. M., and W. J. Harper. 1999. Maximizing the value of milk through separation technologies. J. Dairy Sci. 82:2238-2244. https://doi.org/10.3168/jds.S0022-0302(99)75471-8.

Huisman, I. H., G. Trägårdh, and C. Trägårdh. 1999. Particle transport in crossflow microfiltration-II. Effects of particle-particle interactions. Chem. Eng. Sci. 54:281-289. https://doi.org/10.1016/ S0009-2509(98)00223-1.

Huppertz, T., and C. G. de Kruif. 2007. Disruption and reassociation of casein micelles during high pressure treatment: Influence of whey proteins. J. Dairy Res. 74:194-197. https://doi.org/10.1017/ S0022029906002263.

Huppertz, T., P. F. Fox, K. G. de Kruif, and A. L. Kelly. 2006a. High pressure-induced changes in bovine milk proteins: A review. Biochim. Biophys. Acta. 1764:593-598. https://doi.org/10.1016/j. bbapap.2005.11.010.

Huppertz, T., P. F. Fox, and A. L. Kelly. 2004. High pressure treatment of bovine milk: Effects on casein micelles and whey proteins. J. Dairy Res. 71:97-106. https://doi.org/10.1017/ S002202990300640X.

Huppertz, T., A. L. Kelly, and C. G. de Kruif. 2006b. Disruption and reassociation of casein micelles under high pressure. J. Dairy Res. 73:294-298. https://doi.org/10.1017/S0022029906001725.

Huppertz, T., A. L. Kelly, and P. F. Fox. 2002. Effects of high pressure on constituents and properties of milk. Int. Dairy J. 12:561-572.

Jimenez-Lopez, J. E., N. Leconte, O. Dehainault, C. Geneste, L. Fromont, and G. Gésan-Guiziou. 2008. Role of milk constituents on critical conditions and deposit structure in skimmilk microfiltration $(0.1 \mu \mathrm{m})$. Separ. Purif. Tech. 61:33-43. https://doi. org/10.1016/j.seppur.2007.09.023.
Kolakowski, P., E. Dumay, and J.-C. Cheftel. 2001. Effects of high pressure and low temperature on $\beta$-lactoglobulin unfolding and aggregation. Food Hydrocoll. 15:215-232. https://doi.org/10.1016/ S0268-005X(01)00017-0.

Lee, D. N., and R. L. Merson. 1975. Examination of cottage cheese whey proteins by scanning electron microscopy: Relationship to membrane fouling during ultrafiltration. J. Dairy Sci. 58:14231432.

Li, H., G. Fane, H. G. L. Coster, and S. Vigneswaran. 1998. Direct observation of particle deposition on the membrane surface during crossflow microfiltration. J. Membr. Sci. 149:83-97. https://doi. org/10.1016/S0376-7388(98)00181-1.

López-Fandiño, R. 2006. High pressure-induced changes in milk proteins and possible applications in dairy technology. Int. Dairy J. 16:1119-1131. https://doi.org/10.1016/j.idairyj.2005.11.007.

Marcelo, P. A., and S. S. H. Rizvi. 2008. Applications of membrane technology in the dairy industry. In Handbook of Membrane Separations. A. K. Paddy, S. S. H. Rizvi, and A. M. Sastre, ed. CRC Press, Boca Raton, FL.

Meyer, P., A. Mayer, and U. Kulozik. 2015. High concentration of skim milk proteins by ultrafiltration: Characterisation of a dynamic membrane system with a rotating membrane in comparison with a spiral wound membrane. Int. Dairy J. 51:75-83. https:// doi.org/10.1016/j.idairyj.2015.07.010.

Mohammad, A. W., C. Y. Ng, Y. P. Lim, and G. H. Ng. 2012. Ultrafiltration in food processing industry: Review on application, membrane fouling, and fouling control. Food Bioproc. Techol. 5:1143-1156. https://doi.org/10.1007/s11947-012-0806-9.

Naik, L., R. Sharma, Y. S. Rajput, and G. Manju. 2013. Application of high pressure processing technology for dairy food preservationFuture perspective: A review. J. Anim. Prod. Advances 3:232-241. https://doi.org/10.5455/japa.20120512104313.

Needs, E. C., R. A. Stenning, A. L. Gill, V. Ferragut, and G. T. Rich. 2000. High-pressure treatment of milk: Effects on casein micelle structure and on enzymic coagulation. J. Dairy Res. 67:31-42. https://doi.org/10.1017/S0022029999004021.

Ng, K., M. Haribabu, D. Harvie, D. E. Dunstan, and G. J. O. Martin. 2016. Mechanisms of flux decline in skim milk ultrafiltration: A review. J. Membr. Sci. 523:144-162. https://doi.org/10.1016/j. memsci.2016.09.036.

Pouliot, Y. 2008. Membrane processes in dairy technology-From a simple idea to worldwide panacea. Int. Dairy J. 18:735-740. https://doi.org/10.1016/j.idairyj.2008.03.005.

Rabiller-Baudry, M., G. Gesan-Guiziou, D. Roldan-Calbo, S. Beaulieu, and F. Michel. 2005. Limiting flux in skimmed milk ultrafiltration: Impact of electrostatic repulsion due to casein micelles. Desalination 175(1 SPEC. ISS.):49-59. https://doi.org/10.1016/j. desal.2004.09.022.

Rademacher, B., and H. G. Kessler. 1997. High pressure inactivation of microorganisms and enzymes in milk and milk products. Pages 291-293 in High Pressure Research in the Biosciences and Biotechnology. K. Heremans, ed. Leuven University Press, Leuven, Belgium.

Rao Ramachandra, H. G., M. J. Lewis, and A. S. Grandison. 1994a. Effect of soluble calcium of milk on fouling of ultrafiltration membranes. J. Sci. Food Agric. 65:249-256. https://doi.org/10.1002/ jsfa. 2740650220

Rao Ramachandra, H. G., M. J. Lewis, and A. S. Grandison. 1994b. Flux pattern and fouling of membranes during ultrafiltration of some dairy products. J. Sci. Food Agric. 66:563-571. https://doi. org/10.1002/jsfa.2740660422

Razavi, S. M. A., S. M. Mousavi, and S. A. Mortazavi. 2003. Dynamic prediction of milk ultrafiltration performance: A neural network approach. Chem. Eng. Sci. 58:4185-4195. https://doi.org/10.1016/ S0009-2509(03)00301-4.

Rinaldoni, A. N., C. C. Tarazaga, M. E. Campderrós, and A. Pérez Padilla. 2009. Assessing performance of skim milk ultrafiltration by using technical parameters. J. Food Eng. 92:226-232. https:// doi.org/10.1016/j.jfoodeng.2008.11.009. 
Shi, X., G. Tal, N. P. Hankins, and V. Gitis. 2014. Fouling and cleaning of ultrafiltration membranes: A review. J. Water Process Eng. 1:121-138. https://doi.org/10.1016/j.jwpe.2014.04.003.

Steinhauer, T., M. Marx, K. Bogendörfer, and U. Kulozik. 2015. Membrane fouling during ultra- and microfiltration of whey and whey proteins at different environmental conditions: The role of aggregated whey proteins as fouling initiators. J. Membr. Sci. 489:2027. https://doi.org/10.1016/j.memsci.2015.04.002.

Tan, T. J., D. Wang, and C. I. Moraru. 2014. A physicochemical investigation of membrane fouling in cold microfiltration of skim milk. J. Dairy Sci. 97:4759-4771. https://doi.org/10.3168/jds.2014-7957.

Tong, P. S., D. M. Barbano, and M. A. Rudan. 1988. Characterization of proteinaceous membrane foulants and flux decline during the early stages of whole milk ultrafiltration. J. Dairy Sci. 71:604-612.
Trujillo, A. J., M. Capellas, J. Saldo, R. Gervilla, and B. Guamis. 2002. Application of high hydrostatic pressure on milk and dairy products: A review. Innov. Food Sci. Emerg. Technol. 3:295-307. https://doi.org/10.1016/S1466-8564(02)00049-8.

Trujillo, A. J., V. Ferragut, A. X. Roig-Sagués, and B. Guamis. 2016. Processing of dairy products utilizing high pressure. Pages 553-581 in High Pressure Processing of Food. https://doi.org/10.1007/9781-4939-3234-4.

Voigt, D. D., A. L. Kelly, and T. Huppertz. 2015. High-pressure processing of milk and dairy products. In Emerging Dairy Processing Technologies: Opportunities for the Dairy Industry. 1st ed. N. Datta and P. M. Tomasula, ed. John Wiley \& Sons Ltd., Chichester, UK. https://doi.org/10.1002/9781118560471.ch3. 